\title{
ЗМІНИ РАДІОАКТИВНОСТІ МОЛОКА ТА ПРОДУКТИВНОСТІ КОРІВ ПРИ ЗАСТОСУВАННІ У ГОДІВЛІ КОМПЛЕКСОНАТІВ МІКРОЕЛЕМЕНТІВ МІДІ, МАРГАНЦЮ, ЦИНКУ
}

\author{
Біденко Володимир Миколайович \\ кандидат сільськогосподарських наук, доцент \\ Поліський національний університет \\ ORCID: 0000-0002-6763-277X \\ E-mail: Volodimerbidenko25@ukr.net \\ Трохименко Віта Зигмундівна \\ кандидат сільськогосподарських наук, доцент \\ Поліський національний університет \\ ORCID: 0000-0002-1763-3141 \\ E-mail: trohimenkovita@ukr.net
}

\author{
Антонюк Валентина Володимирівна \\ магістрантка \\ Поліський національний університет \\ E-mail: antonukvalentina@ukr.net
Галицький Павло Станіславович
магістрант
E-mail: halickiypavlo@ukr.net \\ Поліський національний університет
}

Відомо, що мікроелементи по відношенню до радіонуклідів можуть виступати у ролі радіоблокаторів останніх, знижуючи їх засвоєння у шлунковому каналі тварин та перехід у продукцію тваринництва. Дослідження проводилися на молочних коровах чорно-рябої породи у господарстві СТОВ «Полісся» Народицького району Житомирської області. Для цього на молочно-товарній фрермі було відібрано 15 голів корів, сфформованих у три групи по 5 голів у кожній принципом пар-аналогів. Тварини 1-ї контрольної групи отримували господарський раціон до складу якого входили концентровані корми, трава пасовищна, трава підгодівлі. Корови 2-ї та 3-ї дослідних груп крім основного раціону отримували комплексонати мікроелементів міді, марганцю, цинку. Тварини 2-ї групи - комплексонати цинку та марганию, 3-ї дослідної групи - комплексонати міді, марганию, цинку. Раціони тварин за вищевказаними мікроелементами доводилися до норми. Досліджено вплив комплексонатів мікроелементів цинку, марганцю, міді на перехід цезію-137 і стронцію-90 в молоко корів $і$ їх продуктивність в зоні радіоактивного забруднення. Встановлено, що використання вищевказаних препаратів знижує перехід чезію-137 в 1,2 - 2 рази і стронцію-90 в 1,5 рази молоко корів при їх щоденному згодовуванні. Крім того введення вищевказаних добавок сприяло підвищенню молочної продуктивності корів 2-ї дослідної групи на 10,6, 3-ї групи, на 6,3\%, при P>0,05, у порівнянні із продуктивністю тварин 1-ї контрольної групи. Значне збільшення молочної продуктивності корів відмічалося з третього місяия досліду. У молоці корів 2-ї групи спостерігалося збільшення кількості молочного жиру, у тварин 3-ї групи збільшення кількості жиру і білка у порівнянні із молоком корів 1-ї контрольної групи. Вміст жиру і білка у молоці корів 1-ї групи становив - 4,03 і 3,43\%, відповідно, у молоці корів 2-ї групи - 4,2 і 3,47\%, 3-ї групи - 4,2 i 3,57\%, відповідно, при недостовірній різниці. Підгодівля молочних корів комплексонатами мікроелементів міді, марганцю, цинку сприяла збільшення у молоці корів 2-ї групи марганцю, цинку, 3-ї дослідної групи - міді, марганцю і цинку. В організмі тварин 2-ї та 3-ї групи відмічалося покращення імунного статусу за рахунок збільшення у крові кількості еритроцитів, лейкоцитів та лімсоцитів.

Ключові слова: корови, раціон, мікроелементи, комплексонати, радіонукліди.

DOI: https://doi.org/10.32845/bsnau.lvst.2020.2.4.

Постановка проблеми. Для більшості північних районів Полісся, забруднених, ${ }^{137} \mathrm{Cs}$ i ${ }^{90} \mathrm{Sr}$, крім того однією із важливих проблем у годівлі тварин $є$ аліментарна, пов'язана із дефіцитом у кормах, раціонах мікроелементів - міді, марганцю, цинку, кобальту, йоду [1]. Нестача мікроелементів у раціонах тварин, незбалансована годівля за ними призводить до порушення в їх організмі обміну речовин, відповідно зниження продуктивності, погіршення якості одержуваної продукції та прояву певних захворювань $[2,3]$.

Відомо, що у житті тварин мікроелементи відіграють важливу роль, так як входять до складу багатьох ферментів,

гормонів і вітамінів, впливають на обмін білків, жирів та вуглеводів, мінеральних речовин [4]. Внаслідок цього впливу, відповідно активізації обміну речовин в організмі, підвищується продуктивність тварин, покращується якість отримуваної продукції. На сьогодні відомо, що мікроелементи здатні вносити значні зміни у метаболізм радіонуклідів. Між мікроелементами та радіонуклідами можливий різний взаємний вплив, синергізм і антагонізм, адитивна дія тощо. Так, за даними І.М. Гудкова $[5,6,7,8]$ мікроелементи можуть вступати із ними у складні конкурентні відносини, проявляти синергізм до макроелементів, а значить сприяти їх засвоєнВісник Сумського національного аграрного університету 
ню, тим самим створювати для радіонуклідів антагоністичні умови.

Аналіз останніх досліджень. У кінці минулого сторіччя вивчено вплив різних сполук солей мікроелементів на продуктивність корів, якість їх продукції, перехід цезію-137 із раціону в молоко $[9,10]$ проте відсутні дані по вивченню впливу хелатних комплексів, зокрема комплексонатів мікроелементів міді, марганцю та цинку (edds + Zn, Mn, Cu) на продуктивні якості корів, якість одержаного молока та перехід цезію-137 і стронцію-90 із раціону у молоко.
Матеріали та методи досліджень. Експерименти проводилися у Народицькому районі Житомирської області с. Селець, господарстві СТОВ «Полісся» на молочних коровах української чорно-рябої породи. Для цього на молочнотоварній фермі було відібрано 15 голів корів, які були сформовані у три групи по принципу пар-аналогів по п'ять голів у кожній. Досліди проводилися у літній період при пасовищному утриманні корів. Основними кормами для тварин були трава пасовищна, трава підгодівлі та концентровані корми. Дослід проводився за схемою, таблиця 1.

Таблиця 1

\section{Схема досліду}

\begin{tabular}{|c|c|c|c|}
\hline Групи корів & Кількість голів & Порода & Характеристика умов годівлі тварин \\
\hline 1 & 5 & Українська чорно-ряба & ОР - основний раціон: трава пасовищна, скошена трава, концентровані корми \\
\hline 2 & 5 & $-\ll-\ll-\ll-\ll-\ll-$ & OP + комплексонати Zn, Mn (100\% норми) \\
\hline 3 & 5 & $-\ll-\|-\|--\|-\ll-$ & OP + комплексонати Zn, Mn, Сu (100\% норми) \\
\hline
\end{tabular}

Тварини 1-ї контрольної групи одержували основний господарський раціон до складу якого входили: трава пасовищна, трава підгодівлі, 70\% від поживності та концентровані корми у вигляді зерносуміші (20\% вики, 25\% пшениці, $25 \%$ жита, 30\% ячменю), яка становила $30 \%$ від поживності. Корови 2-ї дослідної групи отримували крім основного раціону, комплексонати мікроелементів цинку та марганцю у перерахунку на чистий елемент у нормованій кількості. Тварини 3-ї групи крім основного раціону одержували комплексонати мікроелементів цинку, марганцю, міді, також у нормованій кількості в перерахунку на чистий елемент згідно деталізованих норм годівлі тварин. Комплексонати мікроелементів змішували із концентрованими кормами. Проби молока корів відбирали при проведенні контрольних удоїв, вранці, в обід та увечері, пропорційно від надою. Молоко консервували 10\% хромпіком. У молоці визначали вміст жиру, білка приладом «Екомілк». Крім того визначали кальцій - трилонометричним методом, фосфор - із застосуванням молібденово-ванадієвокислого амонію з послідуючим колориметруванням, мікроелементи мідь, марганець, цинк, кобальт, важкі метали, кадмій - методом атомноадсорційної спектрометрії. Вміст ${ }^{137} \mathrm{Cs}$ у молоці визначали методом гаммаспектрометрії, на приладі СЕГ- 0,5, ${ }^{90} \mathrm{Sr}$, після підготовки зразків (озоленні), на приладі РІ-БГ. Коефіцієнти переходу (Кп) ${ }^{137} \mathrm{Cs}$ i $90 \mathrm{Sr}$ із раціону в молоко корів визначали із відношення питомої активності молока певного радіонукліду до радіоактивності раціону.

Результати досліджень. Встановлено, що підгодівля корів комплексонатами мікроелементів сприяла зменшенню радіоактивності молока за ${ }^{137} \mathrm{Cs}$ i ${ }^{90} \mathrm{Sr}$, таблиця 2.

Таблиця 2

Таблиця 2. Вміст ${ }^{137} \mathrm{Cs}$ i ${ }^{90} \mathrm{Sr}$ у молоці корів, Бк/л

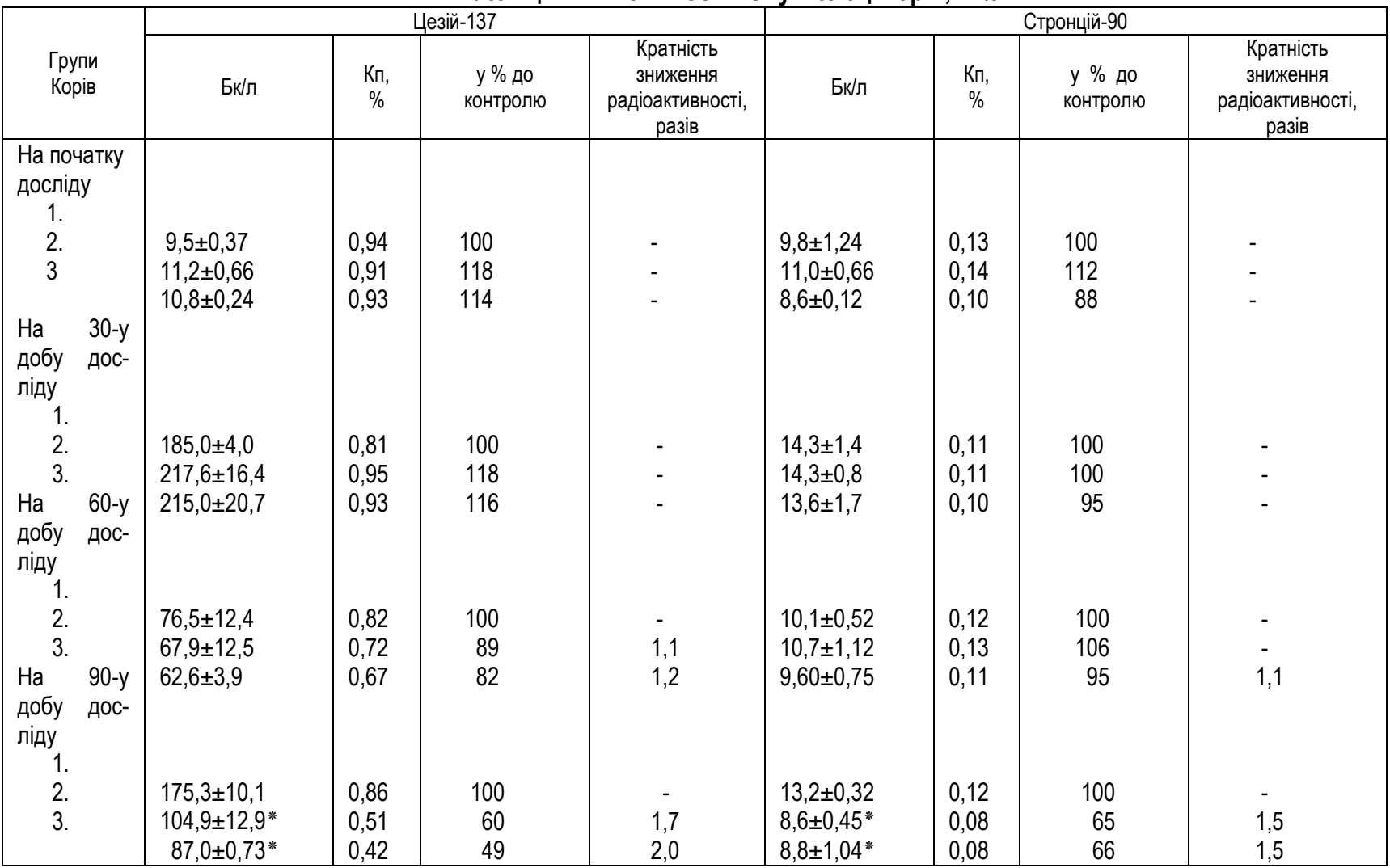


Так як, дослід нами розпочався на кормах зимовостійлового періоду, заготівля яких проводилася на окультурених угіддях, питома активність молока корів по ${ }^{137} \mathrm{Cs}$ i ${ }^{90} \mathrm{Sr}$ у даний період була не високою, в межах 8,6 - 11,2 Бк/л.

Через 30-ть діб, при виході корів на пасовище, радіоактивність трави якого була високою, особливо по цезію137, вміст радіонукліду в молоці значно зріс і складав в межах 185,0 - 217,6 Бк/л, що більше у порівнянні із ДР-2006 в 1,8 - 2,1 рази. На протязі 30-и діб дослідження, підгодівля у даний період корів комплексонатами мікроелементів цинку, марганцю, міді не сприяла зменшенню питомої активності молока тварин.

Вже на 60-у добу експерименту спостерігалося зменшення радіоактивності молока корів дослідних 2-ї та 3-ї груп за ${ }^{137} \mathrm{Cs}$ в 1,1 та 1,2 рази, або на 11 і $18 \%$, відповідно. Так, у корів 1-ї контрольної групи питома активність молока за ${ }^{137} \mathrm{Cs}$ становила - 76,5 Бк/л, 2-ї групи - 67,9 Бк/л, а тварин 3-ї групи - 62,6 Бк/л. Відповідно коефіцієнти переходу (Кп) цезію-137 із раціону в молоко складали - 0,82, 0,72 і 0,67\%, при $\mathrm{P}>0,05$. За ${ }^{90} \mathrm{Sr}$ різниць у питомій активності молока корів виявлено не було.
На 90-у добу досліджень питома активність молока корів 2-ї та 3-ї груп за ${ }^{137} \mathrm{Cs}$ у порівнянні із 1-ю контрольною значно знизилась, меншою була в 1,7 та 2,0 рази, відповідно, за ${ }^{90} \mathrm{Sr}$ була також меншою в 1,5 рази. Так, якщо вміст цезію-137 у молоці тварин 1-ї контрольної групи становив 175,3 Бк/л, то у молоці корів 2-ї групи був - 104,9 Бк/л, що менше на 70,4 Бк, $(P<0,05)$, у корів 3-ї групи активність молока становила 87,0 Бк/л, менше у порівнянні до контролю на - 88,3 Бк, при достовірній різниці $P<0,05$. Кп ${ }^{137} \mathrm{Cs}$ у молоко корів по групах відповідно складали: 0,86, 0,51, 0,42\%. Також відмічалося зменшення активності молока корів 2-ї та 3-ї груп у порівнянні до 1-ї контрольної і за ${ }^{90} \mathrm{Sr}$ на $34-35 \%$, при $\mathrm{P}<0,05$. У тварин 1-ї групи вміст ${ }^{90} \mathrm{Sr}$ у молоці становив - 13,2 Бк/л, 2-ї групи - 8,6 Бк/л, а корів 3-ї групи - 8,8 Бк/л. Коефіцієнти переходу ${ }^{90} \mathrm{Sr}$ із раціону в молоко складали 0,12, 0,08, 0,08\%, відповідно. Мікроелементи сприяли зниженню питомої активності молока корів на 60-у добу досліджень.

Дані впливу комплексонатів мікроелементів на молочну продуктивність корів представлені у таблиці 3.

Таблиця 3

Молочна продуктивність корів за період досліду

\begin{tabular}{|l|c|c|c|c|c|l|}
\hline \multirow{2}{*}{ Показники } & Групи & \multicolumn{5}{|c|}{ Місяці досліду } \\
\cline { 3 - 7 } & корів & \multicolumn{1}{|c|}{1} & 2 & 3 & \multicolumn{1}{c|}{5} \\
& 1 & $285,2 \pm 25,3$ & $331,8 \pm 19,91$ & $295,1 \pm 5,66$ & $194,3 \pm 21,50$ & $64,0 \pm 21,61$ \\
Надій молока, кг & 2 & $297,6 \pm 17,3$ & $343,8 \pm 21,60$ & $373,8 \pm 13,02$ & $212,0 \pm 11,30$ & $68,0 \pm 6,18$ \\
& 3 & $307,7 \pm 16,01$ & $322,8 \pm 19,91$ & $337,9 \pm 8,02$ & $205,0 \pm 29,82$ & $71,0 \pm 26,19 *$ \\
\hline Середньодобовий надій на & 1 & $9,46 \pm 0,84$ & $11,10 \pm 0,66$ & $9,52 \pm 0,18$ & $6,27 \pm 0,69$ & $2,10 \pm 0,72$ \\
корову, кг & 2 & $9,60 \pm 0,56$ & $11,46 \pm 0,76$ & $12,00 \pm 0,42$ & $6,84 \pm 0,36$ & $2,30 \pm 0,20$ \\
& 3 & $9,70 \pm 0,52$ & $10,76 \pm 0,66$ & $10,90 \pm 0,25$ & $6,60 \pm 0,96$ & $2,40 \pm 0,87^{*}$ \\
\hline Відсотки & 1 & 100 & 100 & 100 & 100 & 100 \\
& 2 & 101 & 103 & 126 & 109 & 110 \\
& 3 & 103 & 96 & 114 & 106 & 114 \\
\hline
\end{tabular}

Дані таблиці свідчать, що на 1-му та 2-му місяці досліду надої корів 1-ї контрольної та 2-ї і 3-ї дослідних груп були практично однаковими. Тенденція збільшення надою молока корів 2-ї, 3-ї груп у порівнянні до 1-ї контрольної спостерігалася на 3-му місяці досліджень. Надої молока корів 2-ї та 3-ї груп були більшими у порівнянні із 1-ю контрольною на 26 і 14\%. Так як, дослід на коровах розпочався у квітні місяці, а розтели корів пройшли значно раніше, то на четвертому місяці досліду ми мали значний спад продуктивності всіх дослідних корів. Проте у цей період експерименту у корів 2-ї групи були більші надої на 9\%, у корів 3-ї групи - на 6\%, порівняно з надоями тварин 1-ї групи. На п'ятому місяці досліду у тварин 2-ї та 3-ї груп були більші надої молока на 10 і 14\% (при $\mathrm{P}<0,05)$ у порівнянні із тваринами 1 ї групи.

За дослідний період від корів 2-ї групи було надоєно молока більше на 10,6\%, від тварин 3-ї групи більше лише на 6,3\%, у порівнянні із надоями тварин 1-ї групи.

Підгодівля корів мікроелементами позитивно вплинула на покращення якісного складу молока тварин, таблиця 4.

Таблиця 4

Якісний склад молока дослідних корів

\begin{tabular}{|c|c|c|c|c|}
\hline Групи корів & Суха речовина & Густина & $\%$ жиру & \% Білка \\
\hline 1 кон. & $9,12 \pm 0,093$ & $29,4 \pm 0,12$ & $4,03 \pm 0,08$ & $3,43 \pm 0,03$ \\
\hline 2 & $9,22 \pm 0,126$ & $29,6 \pm 0,08$ & $4,20 \pm 0,06$ & $3,47 \pm 0,08$ \\
\hline 3 & $9,26 \pm 0,090$ & $29,4 \pm 0,17$ & $4,20 \pm 0,11$ & $3,53 \pm 0,06$ \\
\hline
\end{tabular}

Дані таблиці свідчать, що підгодівля корів комплексонатами мікроелементів міді, марганцю, цинку сприяла деякому покращенню якості молока тварин. Так, у молоці корів 2-ї та 3-ї дослідної груп у порівнянні із 1-ю контрольною, які отримували вищевказані добавки відмічалося збільшення кількості жиру, 4,2 і 4,2\%, відповідно, тоді як у корів 1-ї групи вміст жиру в молоці становив - 4,03\%. Кількість білка у молоці тварин 1-ї групи становив - 3,43\%, у молоці тварин 2-ї групи складав - 3,47\%, а у молоці корів 3-ї групи - 3,53\%. Вищевказані дані свідчать, про те, що мікроелементи мідь, марганець і цинк здатні позитивно впливати на якісний склад молока тварин за рахунок збільшення у ньому жиру та білка.

Дані мінерального складу молока корів представлені у таблиці 5. 
Вміст мікроелементів, важких металів у молоці корів, г/л, мг/л

\begin{tabular}{|c|c|c|c|c|c|c|c|c|}
\hline $\begin{array}{c}\text { Групи } \\
\text { корів }\end{array}$ & Са & $\mathrm{P}$ & $\mathrm{Fe}$ & $\mathrm{Co}$ & $\mathrm{Cu}$ & $\mathrm{Mn}$ & $\mathrm{Zn}$ & $\mathrm{Cd}$ \\
\hline 1 кон. & $1,09 \pm 0,06$ & $0,96 \pm 0,07$ & $0,86 \pm 0,03$ & $0,11 \pm 0,01$ & $0,2 \pm 0.06$ & $0,18 \pm 0,005$ & $2,90 \pm 0,06$ & $0,030 \pm 0,003$ \\
\hline 2 & $1,11 \pm 0,05$ & $0,97 \pm 0,07$ & $0,87 \pm 0,07$ & $0,14 \pm 0,02$ & $0,2 \pm 0,01$ & $0,22 \pm 0,014$ & $3,93 \pm 0,09$ & $0,026 \pm 0,003$ \\
\hline 3 & $1,12 \pm 0,011$ & $1,06 \pm 0,03$ & $0,97 \pm 0,07$ & $0,09 \pm 0,09$ & $0,3 \pm 0,012$ & $0,28 \pm 0,09$ & $4,00 \pm 0,0,06$ & $0,023 \pm 0,003$ \\
\hline
\end{tabular}

Із даних таблиці видно, що у молоці корів дослідних груп відмічалася тенденція збільшення кількості міді, у 3-й групі, корови якої підгодовували міддю, у 2-й та 3-й групі марганцю та цинку, тварини даних груп підгодовувалися відповідно цими мікроелементами. Відмічалася позитивна тенденція зменшення у молоці корів 2-ї та 3-ї групи у порівнянні із 1-ю контрольною групою кількості важкого металу кадмію. Так, у молоці корів 1-ї групи вміст кадмію становив 0,03 мг/л, у молоці корів 2-ї та 3-ї групи, 0,026 і 0,023 мг/л, відповідно. Певні позитивні тенденції спостерігалися і по збільшенню у молоці корів 2-ї та 3-ї групи, кальцію та фосфору. На нашу думку мікроелементи, цинк та марганець проявили синергізм до цих макроелементів, відповідно сприяли збільшенню їх кількості у молоці.

Висновки. Підгодівля молочних корів комплексонатами мікроелементів марганцю, цинку сприяла зменшенню питомої активності молока корів за ${ }^{137} \mathrm{Cs}$ в 1,1-1,7 рази. Введення у раціони тварин 3-ї групи міді, марганцю, цинку зменшило активність молока за ${ }^{137} \mathrm{Cs}$ в $1,2-2,0$ рази. Зниження активності молока за ${ }^{90} \mathrm{Sr}$ відмічалося на 90 добу дослідження, в 1,5 рази при достовірній різниці.

Комплексонати мікроелементів цинку та марганцю сприяли збільшенню молочної продуктивності тварин 2-ї групи на 10,6\%, або на 125,2 кг, при P>0,05, корів 3-ї групи, у раціони якої вводили комплексонати міді, марганцю, цинку на 6,3\%, або на 74 кг у порівнянні із тваринами 1-ї контрольної групи ( $P>0,05)$.

У молоці корів 2-ї та 3-ї дослідних груп порівняно з 1-ю контрольною відмічалася тенденція збільшення вмісту жиру, білка, мікроелементів міді, марганцю, цинку та зменшення кількості кадмію.

\section{Список використаної літератури:}

1. Фатаєв А. І., Пащенко Я. В. Фоновий вміст мікроелементів у грунтах України. 2003. 113 с. 1991. 144 c.

2. Судаков М. О., Береза В. І., Погурський В. Г. [та ін.]. Мікроелементози сільськогосподарських тварин. К.: Урожай,

3. Абдурахманов Г. М., Зайцев И. В. Экологические особенности содержания микроэлементов в организме животных и человека. Издательство наука. М: 2004. 280 с

4. Міцик В. Ю. Мікроелементи в годівлі сільськогосподарських тварин. Державне видання. К.: 1962. 161 с.

5. Гудков І. М., Віннічук М. М. Сільськогосподарська радіобіологія. Навч. посіб. Житомир: ДАУ, 2003. 472 с.

6. Біденко В. М. Виділення із молоком, сечею та калом ${ }^{137} \mathrm{Cs}$ з організму дійних корів при підгодівлі їх солями і комплексонатами мікроелементів. Матеріали V з"їду радіобіологічного товариства України (Ужгород. 15-18 вересня 2009 р.). С. 154.

7. Биденко В. Н., Гудков И.Н.Применение комплексонатов микроэлементов в качестве добавок к рациону коров с целью снижения радиоактивности молока. VI сьезд по радиоцинным исследованиям. Тезисы докладов, от 25-28 октября, том 2, М: 2010. С. 79.

8. Гудков И. Н., Лазарев Н. М., Груша В. В., Биденко В. Н. Радиозащитное действие микроэлементов на загрязненных радионуклидами территориях. Российская научная конференция с международным участием (Санк-Петербург. 19-20 мая,. 2011 г.) 2011. С. 33.

9. Чала І. В. Вплив міді, кобальту і йоду на накопичення та виведення цезію-137 і деякі біохімічні показники крові при тривалій дії низьких доз радіації: автореферат дис. ... канд. біологічних наук. : 03.00.13 / [Інститут тваринництва УААН]. м. Харків, 1995. 24 с.

10. Романчук Л. Д. Радіоекологічна оцінка раціонів з різним рівнем мікроелементів як засобу зниження надходження цезію-137 в організм жуйних: автореферат дис. ... канд. сільськогосподарських наук: 06.00.32 і 06.00.16. м. Житомир, 1996. $24 \mathrm{c}$.

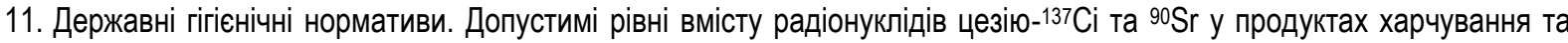
питної води. Офіційний вісник України. 2006. № 29. С. 142.

\section{References:}

1. Fataiev, A. I. and Pashchenko, Ya. V., 2003. Fonovyi vmist mikroelementiv u gruntakh Ukrainy [Background content of microelements in the soils of Ukraine].

2. Sudakov, M. O., Bereza, V. I., Pohurskyi V. H., [et al.], 1991. Mikroelementozy silskohospodarskykh tvaryn [Microelementosis of farm animals]. K.: Urozha.

3. Abdurahmanov, G. M. and Zaytsev, I. V., 2004. Ekologicheskie osobennosti soderzhaniya mikroelementov v organizme zhivotnyih i cheloveka [Ecological features of the content of trace elements in the body of animals and humans]. Izdatelstvo nauka: M.

4. Mitsyk, V. Yu., 1962. Mikroelementy v hodivli silskohospodarskykh tvaryn [Trace elements in the feeding of farm animals]. Derzhavne vydannia. K. 
5. Hudkov, I. M. and Vinnichuk, M. M. Silskohospodarska radiobiolohiia. Navch. posib [Agricultural radiobiology. Tutorial]. Zhytomyr: DAU.

6. Bidenko, V. M., 2009. Vydilennia iz molokom, secheiu ta kalom 137Ss z orhanizmu diinykh koriv pry pidhodivli yikh soliamy i kompleksonatamy mikroelementiv [Excretion with milk, urine and feces $137 \mathrm{Cs}$ from the body of dairy cows when feeding them salts and complexes of trace elements]. Proceedings of the V Congress of the Radiobiological Society of Ukraine, (Uzhhorod. September 15-18, 2009), pp. 154.

7. Bidenko, V. N. and Gudkov, I. N., 2010. Primenenie kompleksonatov mikroelementov v kachestve dobavok k ratsionu korov $s$ tselyu snizheniya radioaktivnosti moloka [The use of complexonates of trace elements as additives to the diet of cows in order to reduce the radioactivity of milk]. VI congress on radiocin research. Abstracts, October 25-28, т. 2, M., pp. 79.

8. Gudkov, I. N., Lazarev, N. M., Grusha, V. V. and Bidenko, V. N., 2011. Radiozaschitnoe deystvie mikroelementov na zagryaznennyih radionuklidami territoriyah [Radioprotective effect of trace elements in areas contaminated with radionuclides]. Russian scientific conference with international participation (St. Petersburg. May 19-20, 2011), pp. 33.

9. Chala, I. V., 1995. Influence of copper, cobalt and iodine on accumulation and removal of cesium-137 and some biochemical indicators of blood at long action of low doses of radiation: the thesis author's abstract. Ph.D of biological sciences. Institute of Animal Husbandry UAAS. Kharkiv.

10. Romanchuk, L. D., 1996. Radioecological assessment of diets with different levels of trace elements as a means of reducing the intake of cesium-137 in the body of ruminants: the thesis author's abstract. Ph.D of agricultural sciences. Zhytomyr.

11. Derzhavni hihiienichni normatyvy, 2006. Dopustymi rivni vmistu radionuklidiv tseziilu-137Cs ta ${ }^{90} \mathrm{Sr}$ u produktakh kharchuvannia ta pytnoi vody [Permissible levels of cesium- ${ }^{137} \mathrm{Cs}$ and ${ }^{90} \mathrm{Sr}$ radionuclides in food and drinking water]. Ofitsiinyi visnyk Ukrainy, no 29, pp. 142.

Bidenko Volodymyr Mykolaiovych, PhD of Agricultural Sciences, Associate Professor

Trokhymenko Vita Zyhmundivna PhD of Agricultural Sciences, Associate Professor

Antoniuk Valentyna Volodymyrivna, Undergraduate

Halytskyi Pavlo Stanislavovych, Undergraduate

Polissia National University (Zhytomyr, Ukraine)

Changes in radioactivity of milk and productivity of cows when used in feeding complexonates of copper elements of copper, manganese, zinc

It is known that trace elements in relation to radionuclides can act as radioblockers of the latter, reducing their absorption in the gastric canal of animals and the transition to livestock products. The research was conducted on dairy cows of black-spotted breed in the farm STOV "Polissia" Narodytskyi district of Zhytomyr region. For this purpose, 15 cows were selected on a dairy farm, formed into three groups of 5 heads in each pair of analogues. Animals of the 1st control group received a household ration which included concentrated forages, a grass of a pasture, a grass of top dressing. Cows of the 2 nd and 3rd experimental groups in addition to the main diet received complexes of trace elements copper, manganese, zinc. Animals of the $2 n d$ group - complexants of zinc and manganese, 3rd experimental group - complexonates of copper, manganese, zinc. The rations of animals for the above trace elements were brought to normal. The influence of complexants of microelements zinc, manganese, copper on the transition of cesium-137 and strontium-90 in the milk of cows and their productivity in the area of radioactive contamination were studied. It is established that the use of the above drugs reduces the transition of cesium- 137 by $1.2-2$ times and strontium-90 by 1.5 times the milk of cows during their daily feeding. In addition, the introduction of the above additives increased the milk productivity of cows of the 2 nd experimental group by 10.6, 3rd group, by $6.3 \%$, at $P>0.05$, compared with the productivity of animals of the 1 st control group. A significant increase in milk productivity of cows was observed from the third month of the experiment. In the milk of cows of the 2nd group there was an increase in the amount of milk fat, in the animals of the 3rd group an increase in the amount of fat and protein in comparison with the milk of cows of the 1st control group. The fat and protein content in the milk of cows of the 1st group was - 4.03 and $3.43 \%$, respectively, in the milk of cows of the 2 nd group - 4.2 and $3.47 \%$, the $3 r d$ group - 4.2 and $3.57 \%$, respective$l y$, with an insignificant difference. Feeding dairy cows with complexes of trace elements copper, manganese, zinc contributed to the increase in milk of cows of the 2nd group of manganese, zinc, 3rd experimental group - copper, manganese and zinc. In the body of animals of the 2nd and 3rd groups there was an improvement in immune status due to an increase in the number of erythrocytes, leukocytes and lymphocytes in the blood.

Key words: cows, diet, microelements, complexonates, radionuclides

Дата надходження до редакції: 04.09.2020 р. 